\title{
PERIDOTITIC PARAGENESIS PLANAR OCTAHEDRAL DIAMONDS FROM THE ELLENDALE LAMPROITE PIPES, WESTERN AUSTRALIA.
}

\author{
A.L. Jacques ${ }^{(1)} ;$ A.E. Hall $^{(2)}$; J. Sheraton ${ }^{(1)} ;$ C.B. Smith ${ }^{(2)}$ and Z. Roksandic ${ }^{(1)}$
}

(1) Bureau of Mineral Resources, Canberra, ACT, Australia; (2) CRA Exploration Pty Ltd, Perth, Werstern Australia.

\section{Introduction}

The $20 \mathrm{Ma}$ Ellendale lamproite pipes, in the West Kimberley province of Western Australia, are the youngest diamond pipes known. Previous studies (Hall \& Smith, 1984; Jaques et al., 1989) have shown that the larger size (>1 mm) diamonds from these pipes are mostly distinctive lustrous dodecahedra containing equal proportions of peridotitic and eclogitic paragenesis inclusions and having a wide range of carbon isotopic compositions $\left(\delta^{13} \mathrm{C}=-3.4\right.$ to $\left.-14.4 \% \%\right)$. New data show that a distinctive suite of small commercial sized $(1.0-2.5 \mathrm{~mm})$ octahedral diamonds from the Ellendale pipes are of peridotitic paragenesis and similar to small octahedral diamonds found in garnet peridotite (dominantly lherzolite) xenoliths from the Argyle lamproite.

\section{Ellendale planar octahedral diamonds}

Amongst the Ellendale diamonds are a distinctive suite of small stones which are typically frosted, step-layered planar octahedra and mostly white to pale brown in colour (Hall and Smith, 1984, fig. 7f). Graphite inclusions are common. Included amongst these stones are hemimorphic forms, half octahedron, half resorbed to dodecahedron (Hall and Smith, 1984, fig. 7e). These are thought to have resulted from partial resorption of diamond protruding from the surface of a xenolith. Subsequent disaggregation of the xenolith released the whole stone with the previously embedded portion retaining its original octahedral form.

The suite contains only peridotitic primary mineral inclusions: olivine, enstatite, olivine + enstatite, Crdiopside, olivine + Cr-diopside, and olivine + Cr-pyrope. Chrome diopside is abundant $(\approx 40 \%$ of stones with primary silicates), as found in previous studies of the Ellendale stones (21\% of peridotitic inclusions), implying a dominantly lherzolite facies derivation.

Olivine ( $\left.\mathrm{Mg}_{90}, 9-92,4\right)$ and enstatite $\left(\mathrm{Mg}_{92}, 6-92,9,0.4-\right.$ $0.7 \% \mathrm{Al}_{2} \mathrm{O}_{3}$ ) lie within the compositional range previously found for inclusions in Ellendale peridotitic diamonds and, overall, are not as Mg-rich as olivine inclusions in diamond worldwide (mostly Mg90.5-92.5 $\mathrm{Cf} \geq \mathrm{Mg}_{92.5}$ ). Chrome diopside $\left(\mathrm{Ca} /(\mathrm{Ca}+\mathrm{Mg})=0.43-0.44,1^{2} \mathrm{i}^{5} .4 \% \mathrm{Cr}_{2} \mathrm{O}_{3}\right)$, and chrome pyrope $\left(\mathrm{Mg}_{84}, \approx 9 \% \mathrm{Cr}_{2} \mathrm{O}_{3}, \approx 6 \% \mathrm{CaO}\right)$ also tall within the compositional range previously established for peridotitic inclusions from Ellendale diamonds. The Ca-saturated nature of the cr-pyrope is consistent with derivation from a lherzolite assemblage.

\section{Temperature-Pressure Estimates}

Equilibration temperatures estimated for inclusions from the Ellendale octahedral diamonds are very similar to those obtained for the Ellendale peridotitic population (1125 $\pm 50^{\circ} \mathrm{C}$ ) using a variety of thermometers (Table 1). A nominal pressure 
of $5 \mathrm{GPa}$ has been assumed where pressures are unknown which seems a reasonable estimate since very similar pressures were calculated for two of the diamonds.

\section{Diamond Assemblage P (GPa) T $\left({ }^{\circ} \mathrm{C}\right)$ Method}

Ellendale: Jaques et al. $\frac{1989}{(5)}$

$\begin{array}{llll}E 4 / 2 & \text { Ol-opx } & (5) & 1115 \\ \text { E4/11 } & \text { Ol-ga } & - & 1100 \\ \text { E4/12 } & \text { Ol-ga } & (5) & 1225 \\ \text { E4/18 } & \text { Ol-opx-cpx } & (5) & 1165 \\ & & 4.50 & 1120 \\ \text { E4/20 } & \text { Opx } & (4.5) & 1090 \\ \text { E4/24 } & \text { Opx } & (5) & 1095 \\ \text { Mean } & & (5) & 1145 \\ & & & 1125\end{array}$

Ca in opx

$\mathrm{Ni}$ in $\mathrm{ga}$

$\mathrm{Fe}-\mathrm{Mg}$ ol-ga

$\mathrm{Ni}$ in ga

$\mathrm{Fe}-\mathrm{Mg}$ ol-ga

$\mathrm{Cpx}-\mathrm{opx} / \mathrm{Ca}$ in ol

$\mathrm{Ca}$ in opx

$\mathrm{Ca}$ in opx

$\mathrm{Ca}$ in opx

Ellendale selected octahedra

$\begin{array}{lllll}\text { E208 } & \text { Opx } & (5) & 1135 & \text { Ca in opx } \\ \text { E209 } & \text { Ol-opx } & (5) & 1020 & \text { Ca in opx } \\ \text { E217 } & \text { Ol-cpx } & 4.47 & (1100) & \text { Ca in ol } \\ \text { E226 } & \text { Ol-ga } & (5) & 1150 & \mathrm{Fe}-\mathrm{Mg} \text { ol-ga } \\ \text { Mean } & & & 1100 & \end{array}$

Argyle: Jaques et al. 1989
A104
ol-opx
(5)
1120
1225
Ca in opx
$\mathrm{Ni}$ in ga
A151
(5)
1150
$\mathrm{Fe}-\mathrm{Mg}$ ol-ga

Note: Thermobarometers given in Brey and Kohler (1990) and Griffin et al. (1989).

These temperatures are slightly higher than those typically obtained for peridotitic inclusions in diamond from kimberlites. Even higher temperatures $\left(1140-1290^{\circ} \mathrm{C}\right.$ ) were obtained from inclusions in diamond and diamondiferous peridotite xenoliths from the Argyle pipe (Jaques et al., 1990). This difference in temperature between Argyle and Ellendale diamonds (especially eclogitic suites) is clearly shown by the much higher level of aggregation of nitrogen in the Argyle diamonds compared to Ellendale stones (Taylor et al., 1990). The mean equilibration temperature for the Ellendale peridotitic diamonds is very similar to that obtained from nitrogen aggregation characteristics for Ellendale 9 peridotitic diamonds for a late Precambrian age of formation (Taylor et al., 1990).

\section{Carbon Isotopic composition}

The Ellendale planar octahedra have a small range in carbon isotopic compositions $\left(\delta^{13} \mathrm{C}=-3.1\right.$ to $-6.2 \%$ oo vs PDB) with a peak of ${ }^{13} \mathrm{C}$ values at $-4.8 \% 0$. These fall within the compositional range found previously for peridotitic diamonds from the Ellendale pipes $\left(\delta^{13} C=-3.9\right.$ to $-6.4 \% / 00$, averaging $-5.2 \%(00)$ and peridotitic suite diamonds from Argyle and elsewhere.

The limited range of the Ellendale peridotitic suite diamonds contrasts with the range of $\delta^{13} \mathrm{C}$ values observed for Ellendale eclogitic paragenesis diamonds which extend to values more depleted in ${ }^{3} \mathrm{C}\left({ }^{13} \mathrm{C}=-3.8\right.$ to $-11.2 \%$ \% $)$. Argyle eclogitic diamonds are even more depleted in ${ }^{3} \mathrm{C}\left(\delta^{13} \mathrm{C}\right.$ 
mostly -9 to $-12 \% / 00$ ) suggesting involvement of significant amounts of recycled crustal carbon (Jaques et al., 1989). Ellendale eclogitic diamonds, by compárison, apparently had a much smaller input of crustal carbon.

\section{origin of the diamonds}

The recognition of an association of a distinctive diamond morphology, namely step-layered octahedra, with exclusively peridotitic paragenesis inclusions and restricted mantle-type! ( $\left.{ }^{13} \mathrm{C} \approx-5 \% / 00\right)$ carbon isotopic composition in the Ellendale diamonds mirrors a similar finding in the Argyle diamonds (Jaques et al., 1990). The Argyle lamproite contains distinctive sharp-edged planar octahedral diamonds which have peridotitic inclusions and small negative $\delta^{13} \mathrm{C}$ values and these have been identified as being derived from diamondiferous peridotite xenoliths of mostly lherzolitic composition.

Microdiamonds at Ellendale, below the size range of the octahedral stones studied in this paper, are of similar planar form and dominant brown or white colour and, may therefore be of similar origin, viz. from primordial mantle carbon in subcontinental peridotitic, mostly lherzolitic, mantle. The less depleted nature (in terms of $\mathrm{Mg} / \mathrm{Fe}$ ) of the inclusions, the relative abundance of chrome diopside inclusions and the Ca-saturated nature of the chrome pyropes suggest a

lherzolitic rather than a harzburgitic source for most of the Ellendale peridotitic diamonds.

The preservation and lack of resorption of these diamonds seems likely to be due to shielding in peridotite xenoliths until a comparatively late stage in the eruption of the lamproites. Shielding of eclogitic paragenesis diamonds has been less effective, possibly because of the lower melting temperature of eclogite and earlier disaggregation of the eclogite xenoliths.

\section{References}

Brey, G.P. and Kohler, T. (1990) Journal of Petrology, 31, $1353-1378$.

Griffin, W.L., Cousens, D.R., Ryan, C.G., Sie, S.H., and Suter, G.F. (1989) Contribùtions to Mineralogy and Petrology, 103, 199-202.

Hall, A.E., and Smith, C.B. (1984) In Glover J.E. and Harrisi P.G. Eds., Kimberlite occurrence and origin, p. 167-212. University of Western Australia Geology Department and Extension, Publication No. 8.

Jaques, A.L., Hall, A.E., Sheraton, J.D., Smith, C.B., Sun, S-S., Drew, R.M., Foudoulis, C., and Ellingsen, K. (1989) In Ross $J$. et al. Eds., Kimberlites and related rocks volume 2: their mantle/crust setting, diamonds and diamond exploration, p.966-989. Geological Society of Australia Special Publication No.14.

Jaques, A.L., O'Neill, H.St.C., Smith, C.B., Moon, J. and Chappell, B.W. (1990) Contributions to Mineralogy and Petrology, 104, 255-276.

Taylor, W., Jaques, A.L., and Ridd, M. (1990) American Mineralogist, in press. 